\title{
References
}

1. Bertin, J. (1983). Semiology of graphics. Wisconsin: University of Wisconsin Press.

2. Hanotska, O. (2011). Dialektychna yednist poniat «forma» ta «zmist»u hrafichnomu dyzaini [The dialectical unity of the concepts of "form" and "content" in graphic design]. Visnyk Kharkivskoi derzhavnoi akademii dyzainu i mystetstv. Seriia: Mystetstvoznavstvo. Arkhitektura, no.6, pp. 19-22.

3. Mykhailenko, V., Yakovliev, M. (2004). Osnovy kompozytsii (heometrychni aspekty khudozhnioho formotvorennia) [Fundamentals of composition (geometric aspects of artistic shaping)]. Kyiv: Karavela.

4. Tafty, E. 'Presentation of information'. Ridli, [online] Available at: $<$ http://readli.net/predstavlenie-informatsii/> [Accessed 15 February 2018].

5. Shevchenko, V. (2004). Kompozitsiia plakata [Poster composition]. Kharkiv: Koloryt.

(С) Божко Т. O., 2018

Стаття надійшла до редакиії: 31.08.2018

УДК 7.02:027.2

Вергунова Наталія Сергївна

кандидат мистецтвознавства,

Харківський національний університет міського господарства імені О. М. Бекетова, вул. Маршала Бажанова, 17, м. Харків, Украӥна https://orcid.org/0000-0002-8470-7956 n.vergunova@gmail.com

Вергунов Серсій Вімалійович кандидат мистецтвознавства,

Харківський національний університет міського господарства імені О. М. Бекетова, вул. Маршала Бажанова, 17, м. Харків, Україна, 61002 https://orcid.org/0000-0003-2603-9782 s.vergunov@gmail.com

\section{СКУЛЬПТУРА ЯК ПРОДУКТ ПРОМИСЛОВОГО ДИЗАЙНУ. ДОСВІД ЗАСТОСУВАННЯ В ПРОЕКТНІЙ ПРАКТИЦІ}

Мета дослідження полягає у виявленні та розгляді терміну «промислова скульптура» в діяльності промислового дизайнера. Методи дослідження полягають у застосуванні комплексу загальнонаукових методі (хронологічний та історико-порівняльний, метод термінологічного аналізу), що сприяв виявленню і розгляду об'єктів промислової скульптури в проектній дизайнерській практиці. Наукова новизна роботи полягає у позначенні певного відокремлення об'єктів промислової скульптури і їх розгляд у вгляді окремого сегмента в сучасній предметній культурі. Висновки. Положення, викладені в статті, свідчать про те, що скульптурні композиції, виконані в жанрі монументально-декоративної пластики можуть бути розглянуті як об'єкти промислового дизайну. Абстрагування від основного об'єкта скульптури - людини (результату), і зосередження на роботі скульптора (процесі) дозволяє виявити певну тотожність 3 процесом роботи промислового дизайнера, якого можна вважати скульптором промислової форми.

Об’ємна дизайнерська форма також будується згідно законів композиції, в тому ж реальному просторі і з урахуванням антропометричних особливостей споживачів, тому створювані дизайнером декоративні композиції формально-абстрактного характеру для 
внутрішнього архітектурного і зовнішнього урбаністичного середовища можна назвати терміном промислова скульптура. Ілюстративний матеріал об'єктів промислової скульптури представлений проектною діяльністю авторів статті.

Крім того, встановлено, що застосування 3D-моделювання позитивно впливає на проект до самого останнього моменту роботи над ним, має більш високу якість об'єкта i сприяє інтеграції дизайнерського проекту в виробничий процес. Такий спосіб дозволяє проводити глобальні модифікації виробу як у процесі дизайн-проектування, так і в процесі виробництва нових об'єктів, і їх майбутніх модифікацій. На основі розглянутих авторських та студентських проектних розробок промислових скульптур можна зазначити, що сприйняття цих об'єктів базується не на понятті масштабності, а на понятті масштабу в контексті пропорційних відносин. Таким чином, головним моментом виступає незмінне співвідношення зорових мас об'єкта, незалежно від його лінійних розмірів.

Ключові слова: промислова скульптура; промисловий дизайн; проектна практика.

Вергунова Наталья Сергеевна, кандидат искусствоведения, Харьковский национальный университет городского хозяйства имени А. Н. Бекетова, г. Харьков, Украина

Вергунов Сергей Витальевич, кандидат искусствоведения, Харьковский национальный университет городского хозяйства имени А. Н. Бекетова, г. Харьков, Украина Скульптура как продукт промышленного дизайна. Опыт применения в
проектной практике

Цель исследования заключается в выявлении и рассмотрении термина «промышленная скульптура» в деятельности промышленного дизайнера. Методы исследования состоят в применении комплекса общенаучных методов (хронологический и историко-сравнительный, метод терминологического анализа), который способствовал выявлению и рассмотрению объектов промышленной скульптуры в проектной дизайнерской практике. Научная новизна работы заключается в обозначении определенного отделения объектов промышленной скульптуры и их рассмотрения в качестве обособленного сегмента в современной предметной культуре. Выводы. Положения, изложенные в статье, свидетельствуют о том, что скульптурные композиции, выполненные в жанре монументально-декоративной пластики, могут быть рассмотрены как объекты промышленного дизайна. Абстрагирование от основного объекта скульптуры - человека (результата), и сосредоточение на работе скульптора (процессе) позволяет выявить определенную тождественность с процессом работы промышленного дизайнера, которого можно считать скульптором промышленной формы.

Объемная дизайнерская форма также строится согласно законам композиции, в том же реальном пространстве и с учетом антропометрических особенностей потребителей, поэтому создаваемые дизайнером декоративные композиции формально-абстрактного характера для внутренней архитектурной и наружной урбанистической среды, могут быть обозначены термином промышленная скульптура. Иллюстративный материал объектов промышленной скульптуры представлен проектной деятельностью авторов статьи.

Кроме того, установлено, что применение 3D-моделирования дает возможность внесения улучшений в проект до самого последнего момента работы над ним, потенциально несет в себе более высокое качество объекта и способствует интеграции дизайнерского проекта в производственный процесс. Такой способ позволяет проводить глобальные модификации изделия, как в ходе дизайн-проектирования, так и в процессе производства новых объектов, и их будущих модификаций. На основе рассмотренных авторских и студенческих проектных разработок промышленных скульптур можно отметить, что восприятие этих объектов базируется не на понятии масштабности, а на понятии масштаба в контексте пропорциональных отношений. Таким образом, главным моментом выступает неизменное соотношение зрительных масс объекта, независимо от его линейных размеров.

Ключевые слова: промышленная скульптура; промышленный дизайн; проектная практика. 
Verhunova Nataliia, PhD in Art Criticism, O. M. Beketov National University of Urban Economy in Kharkiv; 17, Marshal Bazhanov St, Kharkiv, Ukraine

Verhunov Serhii, PhD in Art Criticism, O. M. Beketov National University of Urban Economy in Kharkiv; 17, Marshal Bazhanov St, Kharkiv, Ukraine

\section{Sculpture as an industrial design product. Application in design practice}

The purpose of the article is to reveal and consider the term «industrial sculpture» in the context of the activity of an industrial designer. The research methodology consisted in applying a set of general scientific methods (chronological and historical-comparative, the method of terminological analysis), which helped to identify and examine examples of industrial sculpture in design practice. The scientific novelty of the work lies in categorizing the objects of industrial sculpture and their consideration as a separate segment in modern material culture. Conclusions. The article reveals that sculptural compositions made in the genre of monumental and decorative plastics can be considered as objects of industrial design. At the same time, abstracting from the main object of sculpture - the person (result) - and focusing on the sculptor's work (process) allows for revealing a certain identity with the work process carried out by the industrial designer, who can be considered a sculptor of the industrial form.

The volumetric design form is also built according to the laws of composition, in the same real space and in compliance with the anthropometric features of consumers; therefore, decorative formal-abstract designs created by the designer for the interior architectural and the exterior urban environment can be designated by the term «industrial sculpture». Illustrative material to the objects of industrial sculpture is represented by the design activity of the authors of this article.

It was also revealed that the use of 3D-modeling affords an opportunity to improve the project until the very last moment of working on it, makes a better quality product and facilitates integration of the design project into the production process. This method allows for carrying out global modifications of the product both in the course of design and in the process of producing new objects and their future modifications. As a result of the study of author and student designs of industrial sculptures, it can be stated that the perception of these objects is not so much based on the concept of immensity as on the concept of scale in the context of proportional relations. Thus, the main point is the constant ratio of visual masses of the object, regardless of its linear dimensions.

Key words: industrial sculpture; industrial design; design practice.

Вступ. Якщо абстрагуватися від основного об’єкта скульптури - людини (результату) i зосередитися на роботі скульптора (процесі), то можна виявити дивовижну схожість 3 процесом роботи промислового дизайнера. Об'ємна скульптурна форма будується в реальному просторі за законами гармонії, ритму, рівноваги, взаємодії з навколишнім архітектурним або природним середовищем i на основі спостережуваних в натурі анатомічних особливостей тієї чи іншої моделі (Балицкая ред., 2007, с. 457). Об'ємна дизайнерська форма будується в тому ж реальному просторі, згідно тих же законів композиції, на основі антропометричних особливостей того чи іншого споживача. Єдиною важливою помітною особливістю цих процесів є облік конструкторського і технологічного факторів у дизайнерській праці та їх відсутність у роботі скульптора. Таким чином, можна впевнено стверджувати, що робочий процес цих фахівців тотожний.

Останнім часом такі «скульптурні» об’єкти, виконані промисловим дизайнером, активно використовуються у міському середовищі для гармонійної організації суспільного простору. При цьому чітко визначеної дефініції «промислова скульптура» не має - вона не описана та не сформульована, а коло об'єктів, які теоретично можуть належати до цього поняття, не систематизовано та не структуровано. Також частиною цієї наукової проблеми $\epsilon$ відсутність аналізу таких об'єктів з точки зору формоутворення та, як слідство, не описані характерні особливості їх художньо-пластичних рішень. Окреслена наукова проблема $\epsilon$ широкою за своїм значенням та охоплює цілу низку питань з різних напрямків дизайну, тому в даній статі доцільно зосередитися на термінологічному аспекті, проілюстрував ці теоретичні викладки практичною діяльністю та реалізованими продуктами «промислової 
ISSN 2410-1176 (Print) Вісник КНУКіМ. Серія Мистецтвознавство. Вип. 39. ISSN 2616-4183 (Online)

скульптури». У загальнотеоретичному осмисленні обраної тематики використані роботи В. Папанека (2004), С. Валеріус (1973), К. Ульріха, С. Эппінгера (2007). Варто зазначити, що досліджень, які займаються подібною тематикою в контексті промислового дизайну не виявлено.

Мета дослідження полягає у виявленні та розгляді терміну «промислова скульптура» в діяльності промислового дизайнера. Методи дослідження базуються на застосуванні комплексу загальнонаукових методі (хронологічний та історико-порівняльний, метод термінологічного аналізу), що сприяв виявленню і розгляду об'єктів промислової скульптури в проектній дизайнерській практиці. Наукова новизна роботи полягає у позначенні певного відокремлення об'єктів промислової скульптури та іiі розгляд у вигляді окремого сегмента в сучасній предметній культурі.

Виклад основного матеріалу. На початковому етапі проектування дизайнер може оперувати «формотворною масою» в процесі створення «ручних» ескізів майбутнього проекту в плоскій графіці при імітації об'ємної форми або, в результаті комп’ютерних побудов, може використовувати твердотільне моделювання. Це дозволяє «відсікати або прирощувати» різноманітні обсяги і елементи до майбутнього виробу, фактично «ліпити його тіло».

Особливо ці алгоритми помітні в процесі 3D-моделювання в CAD-програмах. Тільки потім, коли тіло в цілому сформовано, коли знайдені його пропорції та визначені співвідношення зорових мас його елементів, «підключаються» інші проектні чинники: конструкція, технологія та інші. Іноді ці фактори можуть кардинально змінити форму об'єкта, що проектується, але це інший аспект розглядуваної проблеми. Тому на початковому етапі ескізування, в частині процесу проектування, термінологія скульптури і промислового дизайну має однакові коріння.

Одним з активно трансформованих жанрів скульптури, особливо на території країн СНД, став жанр монументально-декоративної пластики, представлений декоративними композиціями формально-абстрактного характеру, що встановлюються в умовах міського середовища. Вони не мають виразно-смислового значення і характерні більш художньопластичною складовою. Певною мірою ці композиції співзвучні вправам відомого курсу пропедевтичної підготовки дизайнерів в Bauhaus. Таким чином, об'єкти цього жанру скульптури добре знайомі й зрозумілі промисловим дизайнерам, які пройшли професійну підготовку.

Ще одним важливим аспектом цієї проблеми $\epsilon$ елементна база i технології виробництва створюваних предметів. Під елементної базою, в даному випадку, потрібно розуміти різноманітний сортамент металопрокату, як найбільш довговічного і практичного матеріалу для подібних виробів. Використовуючи цей сортамент (труби: сталеві водогазопровідні, тонкостінні електрозварні, квадратні, прямокутні; сортовий і листовий металопрокат: куточок, квадрат, смуга, швелер, балка таврова і двотаврова, шестигранник, круг (пруток) та ін.) і промислові технології (зварювання, пайка, клепка, фрезерування, токарна обробка, свердління та ін.), дизайнер може створювати декоративні композиції формально-абстрактного характеру для внутрішнього архітектурного i зовнішнього урбаністичного середовища, які можна назвати терміном промислова скульптура. Як і будьякий об'єкт індустріального дизайну, промислова скульптура побудована на однакових композиційних законах і підкоряється всім формотворчим принципам, якими користується при проектуванні дизайнер. Однак існують характерні особливості й відмінності в об'єктах промислової скульптури, на які потрібно звернути увагу. Головна характерна особливість об’єктів промислової скульптури - це відсутність масштабності, однієї з принципово важливих характеристик, що використовуються при проектуванні в промисловому дизайні (рис.1). 


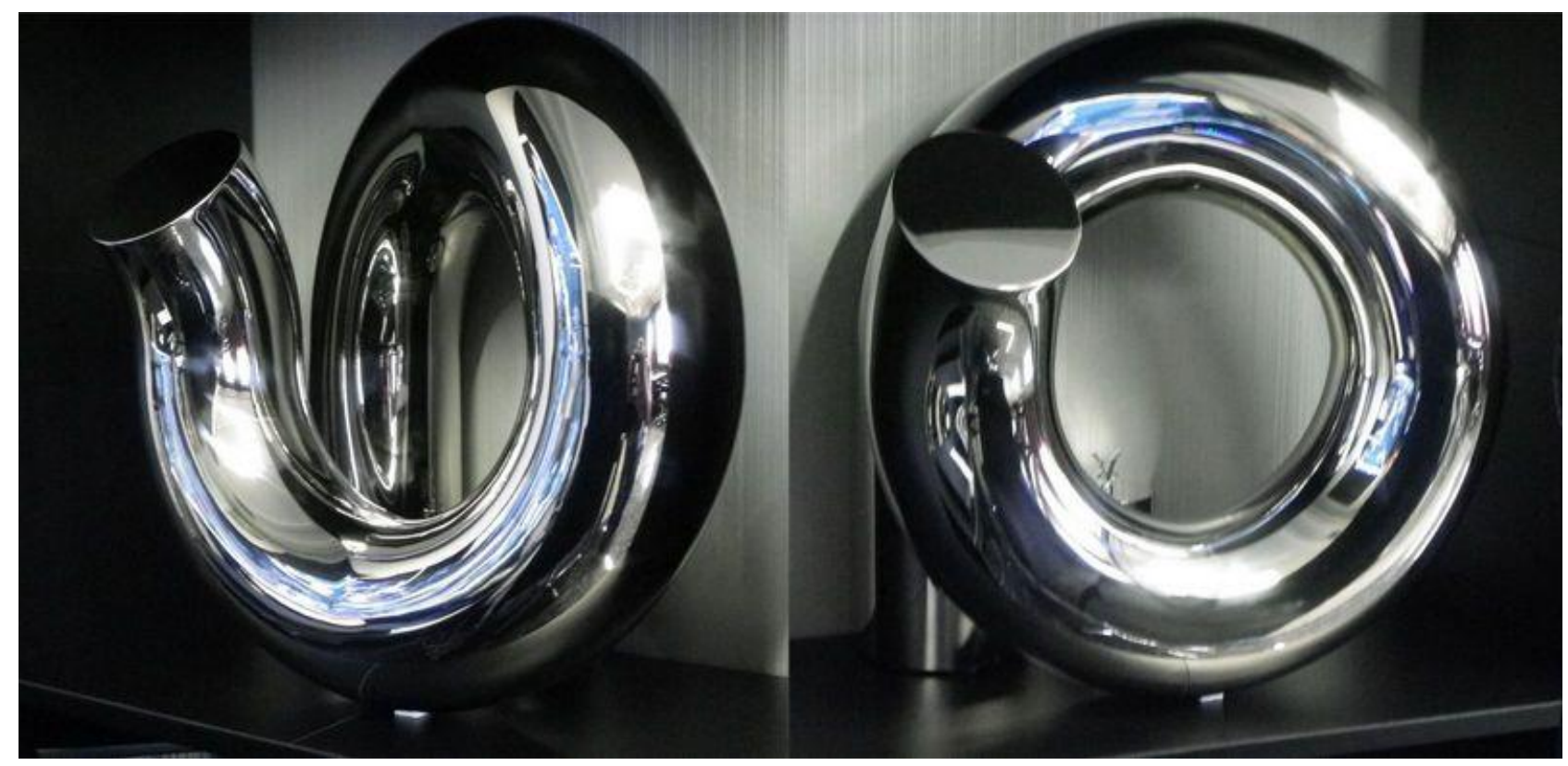

Рисунок. 1. Вергунов С. В., Вергунова Н. С. Промислова скульптура

Figure 1. Vergunov S.V, Vergunova N. S. Industrial sculpture

Масштаб (нім. Мaßstab, букв. «Мірна палиця»: Мaß «міра», Stab «палиця») - в загальному випадку відношення двох лінійних розмірів. У багатьох сферах практичного застосування масштабом називають відношення розміру зображення до розміру зображуваного об'єкта (Ушаков, 2014, с. 289). У дизайні, як і в інших видах образотворчих мистецтв, термін «масштаб» трансформувався в поняття масштабність - відношення величини об'єкта до зросту людини.

Величина архітектурної споруди, розмір картини або скульптури - поняття відносні. Дійсні фізичні вимірювання в образотворчому мистецтві не відіграють великої ролі. Важливі відносини. Зорова величина залежить від масштабності. Наприклад, в Єгипетській піраміді відсутні звичні деталі, співвідносні з ростом людини, такі як вікно, дверний отвір. Тому зору важко орієнтуватися в розмірах споруди, і піраміда, особливо здалеку, не здається такою величезною, якою вона є насправді (Ожегов та Шведова, 2006, с. 345).

У промисловому дизайні масштабність має важливе значення: всі, без винятку об'єкти промислового дизайну проектуються для людини і безпосередньо пов'язані з ним. У цьому випадку масштабність може розглядатися як окремий випадок антропоморфізму в дизайні і в методиці антропометрії. У формоутворенні цих об'єктів завжди присутні функціональні елементи, співмірні з частинами людського тіла, тому увага до них, вже як до елементів композиції, відбувається через поняття масштабності. Надмірне збільшення цих елементів призводить до того, що зір людини оцінює їх за звичними мірками, і вся композиція в цьому випадку здається менше. Інша особливість масштабності полягає в тому, що форми, які асоціюються зі знайомими елементами невеликого лінійного розміру - кнопка, рукоятка, індикатор, - розміщені в об'ємно-просторову структуру великого об'єкта, підкреслюють його правильну тектоніку (верстат, меблі).

Схожа ситуація існує і в художній творчості, живопису, наприклад. Картина є «віртуальним предметом» і справжні розміри зображених на ній об'єктів неважливі. Зображуваний простір у картинній площині створюється тільки відчуттям масштабності для чого в цей простір вводяться мірні елементи: фігури людей, будівлі або добре знайомі предмети. За рахунок перспективних скорочень, відносин величин (контрастів і нюансів), перекривання планів та інших прийомів художник зображує на площині глибину, і глядач подумки «входить» в картину, рухається за маршрутом художника уздовж заданих орієнтирів. Так масштабність народжує спрямованість форми. Маленька за розміром картина може викликати враження величезного простору, і навпаки, велика картина, що досить часто 
ISSN 2410-1176 (Print) Вісник КНУКіМ. Серія Мистецтвознавство. Вип. 39. ISSN 2616-4183 (Online)

трапляється в академічного живопису, сприймається штучно збільшеною мініатюрою (Ожегов та Шведова, 2006, с. 345).

Щодо об'єктів промислової скульптури, то поняття масштабності повністю нівелюється. Більшість таких об'єктів, побудованих у реальному просторі за законами гармонії, ритму, зорової рівноваги та інших категорій композиції, не мають ніякого виразносмислового значення і характерні тільки художньо-пластичній складовій. Цей фактор і $є$ визначальним в іншому сприйнятті терміну масштабності під час проектування об'єктів промислової скульптури.

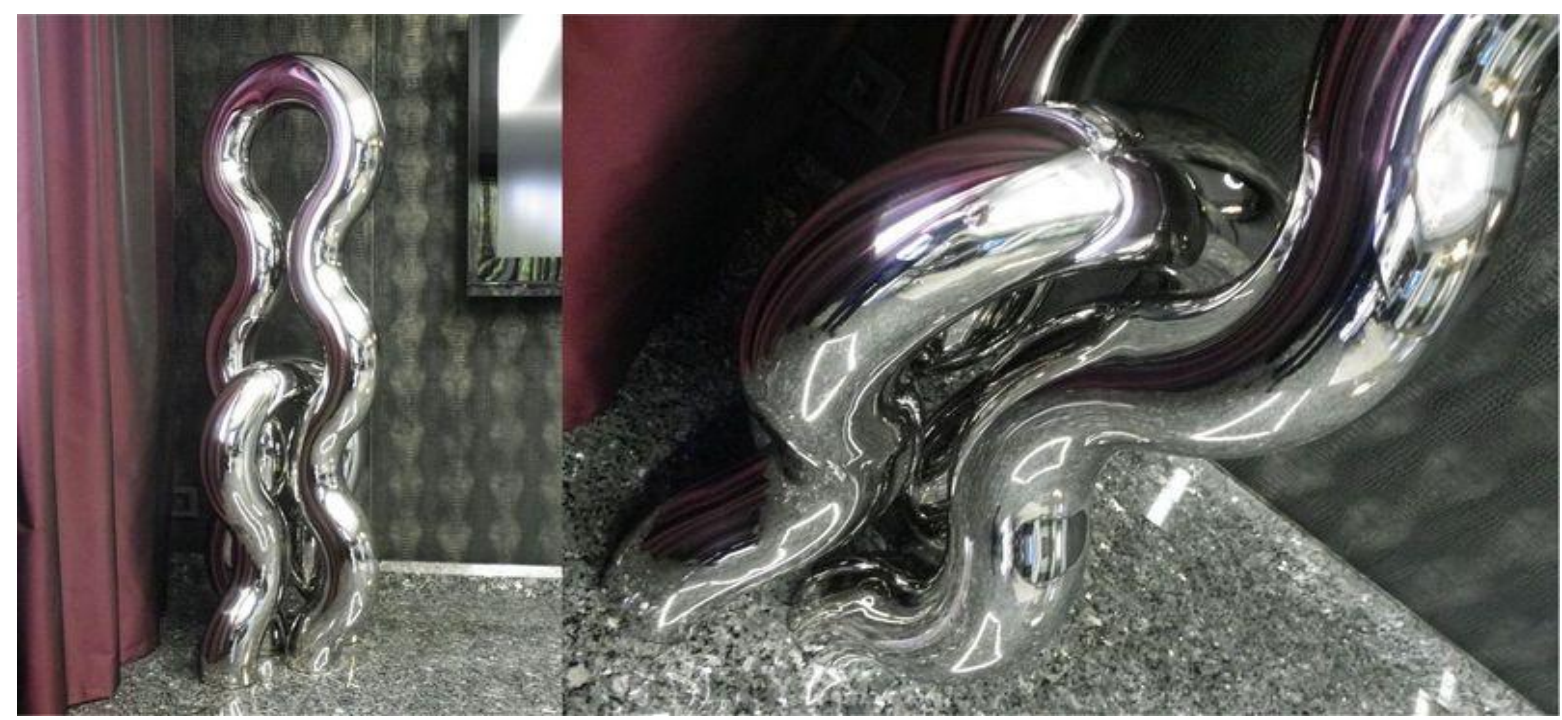

Рисунок 2. Вергунов С. В., Вергунова Н. С. Промислова скульптура «СOITUS»

Figure 2. Vergunov S.V, Vergunova N. S. Industrial sculpture «COITUS»

Розглянемо конкретний приклад. У 2011 р. для оформлення інтер'єрів приватних бізнес-апартаментів було спроектовано кілька декоративних об'єктів - промислових скульптур. Усі вони були виконані в металі й розташовані в інтер'єрах офісу. Частина 3 них була встановлена на прилеглій до офісу території. Одна 3 композицій, яка називається «COITUS» і заввишки 1700 мм, позиціонується як для підлоги і за задумом автора повинна використовуватися в інтер'єрі (рис.2). Така орієнтація передбачає певну систему сприйняття цього об'єкта - він співмірний до росту людини і глядач сприймає цей об'єкт відносно своїх антропометричних даних. Це є перше сприйняття. Тепер уявімо, що ми, без зміни пропорцій, збільшуємо цей об’єкт у десять разів - він має висоту 17000 мм, тобто 17 метрів. У цьому випадку він може бути встановлений тільки в міському середовищі, і може відігравати роль декоративної прикраси навколишнього простору. Глядачі будуть сприймати його як щось велике і монументальне, хоча інтуїтивно, порівняння зі своєю антропометрією триватиме. Це друге сприйняття. А тепер уявімо, що цей об'єкт має висоту 170 мм. Його можна поставити на стіл і використовувати, наприклад, як пап’є-маше. Це третій випадок сприйняття. Якщо їх узагальнити, то виявиться, що i в першому, i в другому, i в третьому випадках масштабність об'єкта не має ніякого значення - в кожному 3 них споживач більше співвідносить об'єкт, який сприймається 3 навколишнім середовищем, 3 можливою функціональною складовою, ніж з власними антропометричними даними.

Дійсно, сприйняття цих об'єктів базується не на понятті масштабності, а на понятті масштабу в контексті пропорційних відносин. У цьому випадку головним моментом виступає незмінне співвідношення зорових мас об'єкта, незалежно від його лінійних розмірів. Інакше кажучи, вносячи відповідні зміни - mutatis mutandis - в лінійні розміри промислової скульптури, її пропорційні відносини повинні зберегтися в стані зародження, в момент утворення - in statu nascendi.

Для майбутнього вивчення цієї проблеми і виявлення ширших практичних результатів, виконаних різними авторами, і відповідно отримання нових теоретичних 
висновків, в рамках випускного бакалаврського проекту 2012 р., під керівництвом Вергунова C. В, восьми студентами 4 курсу спеціальності 6.0202.07 «Дизайн» спеціалізації «Промисловий дизайн» Харківської державної академії дизайну і мистецтва було виконано завдання «Комплект промислових скульптур». Кожен із студентів займався розробкою трьох виробів: об'єкт для міського середовища, ландшафтний об'єкт та виріб, що може бути розміщений в інтер'єрі з додатковою функцією.

Так студент Буценко О. в ролі першого об’єкту розробив композицію для міського середовища Харкова, для якого характерна велика кількість пам'яток у стилі конструктивізму. Композиція промислової скульптури представлена розділеним кубом із кольоровими та пластичними акцентами, яка спирається на металеві стрижні. При цьому порядок розташування стрижнів не є геометрично обгрунтованим, що створює контраст у композиції, між правильною геометрією кубів і грою легких форм стрижнів, які в той же час є несучими для даної конструкції (рис. 3).

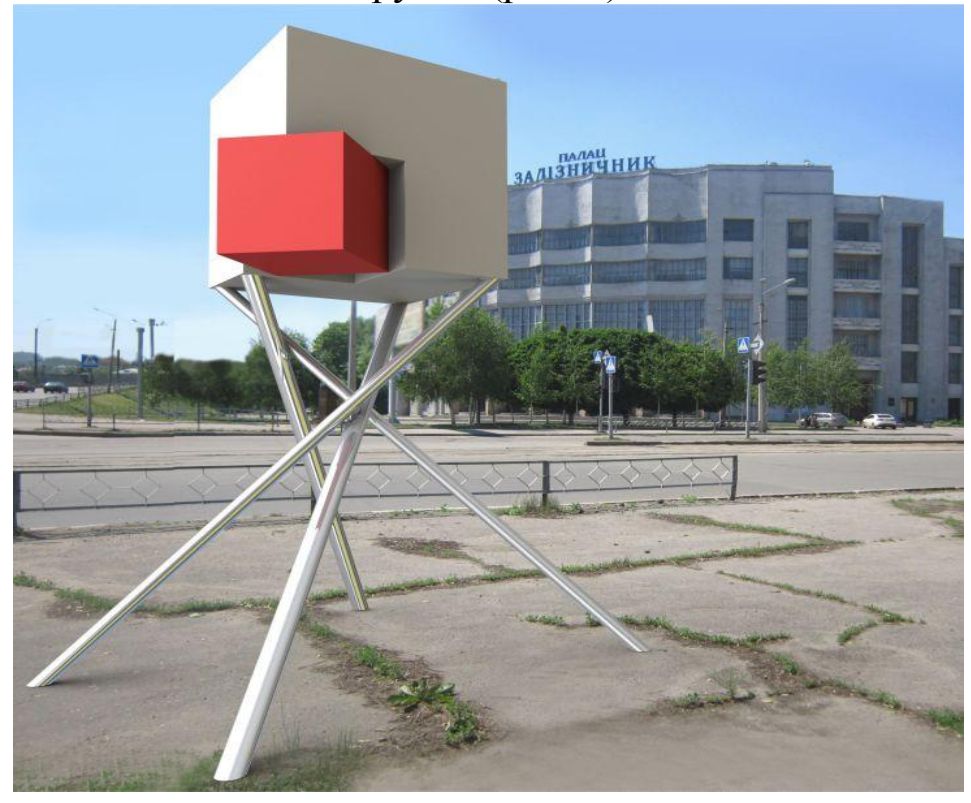

Рисунок. 3. Буценко О. Промислова скульптура для міського середовища Харкова. Керівник С. В. Вергунов Figure 3. Butsenko O. Industrial sculpture for the urban environment of Kharkiv. Head S.V. Vergunov

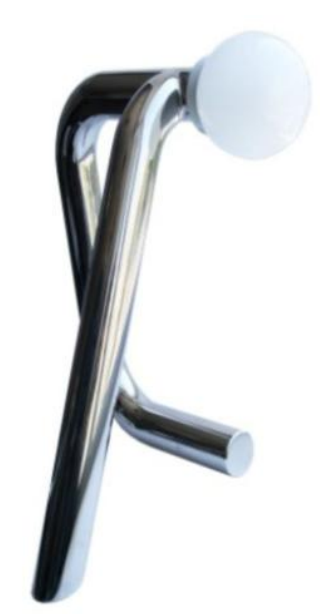

Рисунок. 4. Буценко О. Настільний світильник. Кер. Вергунов С. В. Figure 4. Butsenko O. Table lamp. Head Vergunov S. V.
Під час розробки другого об'єкту для художнього оформлення садово-паркових зон міста студент Буценко О. використовував стандартний металевий сортамент у якості елементів: частини труб, зварені між собою та їх перехідники. Цей підхід забезпечує комбінаторність композиції i різноманіття виконання різних варіантів форми. Для кольорово-фактурного рішення можливе використання металу 3 певним ступенем фактурності, але оптимальним варіантом $є$ полірований метал, що найбільш виразно підкреслює формоутворення об'єкту. Плавні лінії об'єкта можуть відмінно поєднуватися з ландшафтом, повторюючи природні форми.

Виріб для розміщення в інтер'єрі, розроблений студентом Буценко О., є настільнім світильником із металевої труби.

Художньо-образна складова об'єкту заснована на естетиці лаконічних та технологічних форм 3 відповідним стриманим кольорово-фактурним рішенням. Як джерело світла використовується куляста люмінесцентна лампа, що дає хороше рівне світло 3 потужністю 60 Вт, що цілком достатньо для 
додаткового освітлення робочого місця. Таким чином, цей функціональний об'єкт був виконаний на основі форми промислової скульптури (рис.4).

Ще раз зауважимо, що предметна і гносеологічна сторони будь-якої проблеми тісно взаємопов'язані. I в нашому випадку - це недостатня поінформованість про реальну проектну ситуацію, а точніше про ii результати в якості затребуваності дизайнерського продукту в сучасному суспільстві і модних напрямках у сучасному промисловому дизайні, внаслідок чого неможливо використовувати вже наявне знання для з'ясування і можливого врегулювання, на перший погляд, абсолютно різних процесів. I розглядається тут про відповідність об'єкта проектування паспорту спеціальності бакалавра дизайну, а про відповідність паспорту спеціальності сьогоднішнім реаліям.

Ця проектна проблема в цілому, поки не усвідомлюється як нагальна потреба, бо умови, що іiі провокують, не зрозумілі більшості проектантів. Нарешті, будучи усвідомленою, вона не обов'язково стає предметом аналізу і цілеспрямованих дій, так як для цього потрібна активна зацікавленість (а у кожного дизайнера $є$ коло своїх інтересів, i промислова скульптура може туди не входити) і готовність до практичних перетворень на всіх рівнях (викладацьких, кафедральних, академічних) дизайнерських сил. Саме така готовність (що межує 3 самовідданістю) до змін і зацікавленість у появі нових форм навчального процесу, утворюють основу «соціального запиту» в дослідженні нових об'єктів i тем для навчання студентів. Це абсолютно необхідно в сучасних реаліях набору абітурієнтів. В іншому випадку дизайнерська школа поступово, але впевнено буде втрачати свої позиції на ринку надання навчальних послуг спеціалізації «Промисловий дизайн».

Висновки. Положення, викладені в статті, свідчать про те, що скульптурні композиції, виконані в жанрі монументально-декоративної пластики можуть бути розглянуті як об'єкти промислового дизайну. Абстрагування від основного об'єкта скульптури людини (результату), і зосередження на роботі скульптора (процесі) дозволяє виявити певну тотожність 3 процесом роботи промислового дизайнера, якого можна вважати скульптором промислової форми.

Об’ємна дизайнерська форма також будується згідно законів композиції, в тому ж реальному просторі й з урахуванням антропометричних особливостей споживачів, тому створювані дизайнером декоративні композиції формально-абстрактного характеру для внутрішнього архітектурного і зовнішнього урбаністичного середовища можна назвати терміном промислова скульптура. Ілюстративний матеріал об'єктів промислової скульптури представлений проектною діяльністю авторів статті.

Крім того, встановлено, що застосування 3D-моделювання позитивно впливає на проект до самого останнього моменту роботи над ним, потенційно має більш високу якість об'єкта і сприяє інтеграції дизайнерського проекту в виробничий процес. Такий спосіб дозволяє проводити глобальні модифікації виробу як в процесі дизайн-проектування, так і в процесі виробництва нових об’єктів, і їх майбутніх модифікацій. На основі розглянутих авторських та студентських проектних розробок промислових скульптур можна відмітити, що сприйняття цих об'єктів базується не на понятті масштабності, а на понятті масштабу в контексті пропорційних відносин. Таким чином, головним моментом виступає незмінне співвідношення зорових мас об’єкта, незалежно від його лінійних розмірів.

Майбутнє дослідження буде скероване на виявлення характерних особливостей об'єктів промислової скульптури, вивчення проблем 3D-моделювання в проектному процесі, в контексті дизайнерського поля України.

\section{Список використаних джерел}

1. Валериус С. С. Прогрессивная скульптура ХХ века. Проблемы и тенденции. Москва : Изобразительное искусство, 1973. 419 с.

2. Интерьеры частного офиса в г. Харькове. URL:

http://gira.com.ua/konkurs2010.php?view=144 (дата звернення: 24.10.2018 г.) 
3. Искусство. Современная иллюстрированная энииклопедия / под ред.

Т. В. Балицкой. Москва : Росмэн-Пресс, 2007. 608 с

4. Ожегов С. И., Шведова Н. Ю. Толковый словарь русского языка. Москва : ООО «А ТЕМП», 2006. $944 \mathrm{c.}$

5. Папанек В. Дизайн для реального мира. Москва : Аронов, 2004. 416 с.

6. Ульрих К., Эппингер С. Промышиленный дизайн : создание и производство продукта / пер. с англ. М. Лебедева, под общ. ред. А. Матвеева. Москва : Вершина, 2007. 448 с.

7. Ушаков Д. Н. Толковый словарь современного русского языка. Москва : Аделант, 2014. $800 \mathrm{c}$.

\section{References}

1. Balitska, T. ed. (2007). Iskusstvo. Sovremennaya illyustrirovannaya entsiklopediya [Art. Modern illustrated encyclopedia]. Moscow: Rosmen-Press.

2. Valerius, S. (1973). Progressivnaya skul'ptura XX veka. Problemy $i$ tendentsii [Progressive sculpture of the $20^{\text {th }}$ century. Problems and Trends]. Moscow: Izobrazitel'noe iskusstvo.

3. Inter'ery chastnogo ofisa $v$ g. Khar'kove [Interiors of a private office in Kharkiv], [online] Available at: <http://gira.com.ua/konkurs2010.php?view=144> [Accessed 24 October 2018].

4. Ozhegov, S., Shvedova, N. (2006). Tolkovyi slovar' russkogo yazyka

[Explanatory Dictionary of the Russian Language]. Moscow: A TEMP. Aronov.

5. Papanek, V. (2004). Dizain dlya real'nogo mira [Design for the real world]. Moscow:

6. Ulrich, K., Eppinger S. (2007). Promyshlennyi dizain : sozdanie i proizvodstvo produkta. [Product design and development]. Moscow: Vershina.

7. Ushakov, D. (2014). Tolkovyi slovar' sovremennogo russkogo yazika [Explanatory Dictionary of the Modern Russian Language]. Moscow: Adelant.

(C) Вергунова Н. C., 2018

(C) Вергунов С. В. 2018

Стаття надійшла до редакиії 29.10.2018 